\title{
THE RE-IMAGINATION OF A LETTER- WRITER AND THE DE-CONSTRUCTION OF AN OVIDIAN RAPE NARRATIVE AT ARS AMATORIA 1.527-64
}

\author{
By Despina Keramida
}

\begin{abstract}
Summary: Ovid's writing is infused with the re-telling of known myths and the portrayal of heroes and heroines, whose figurae held a central role in Greek and Roman literature. This article argues in favour of reading Ariadne's story at Ars am. 1.527-64 as a rape narrative. The exploration of the passage in question and its comparative reading with other poems (such as Prop. 1.3 and the Ovidian version of the rape of the Sabine women), illustrates and explains why Ovid re-imagines Ariadne as a victim of erotic violence.
\end{abstract}

\section{INTRODUCTORY REMARKS}

It is generally acknowledged that Ovid's work is characterised by different types of repetition, especially in his earlier works such as the Heroides and the Ars Amatoria. ${ }^{1}$ Nevertheless, this re-introduction of heroines and mythological narratives is not limited to mere repetition. On the contrary, it often takes the form of re-interpretation and re-imagination of wellknown stories. One of the most well-known examples of Ovidian repetition and - as this article suggests - of re-imagination is that of Ariadne,

1 As Sharrock 2002: 150 underlines 'much of Ovid's amatory work is infused with an aesthetics of repetition: of material, of style, of himself, and in his characters'. On Ovidian repetition within the Ars Amatoria in particular see Martelli 2013: 68-103.

Despina Keramida 'The Re-Imagination of a Letter-Writer and the De-Construction of an Ovidian Rape Narrative at Ars Amatoria 1.527-64' C\&M 67 (2019) 153-187. 
whose story appears three times in the poet's corpus, ${ }^{2}$ with the first extant account appearing at Heroides 10, continuing in the Ars Amatoria (1.527-64) and concluding in the Fasti (3.459-516). The scholarly approach to the Ovidian accounts of this mythological story displays a certain tendency to discuss the three passages either in relation to each other or in comparison to the Catullan ecphrasis that presents the first extensive version of Ariadne's myth, focusing on matters of allusion. ${ }^{3}$

This article diverges from other scholarly readings by discussing and focusing primarily on the second Ovidian version of Ariadne - as it is narrated in the Ars Amatoria - aiming to illustrate its major narrative variation. Of the three Ovidian passages, the Ars Amatoria version appears to have drawn little scholarly interest (in comparison to the other two passages), mainly because of its length and its function as a digression. The general consensus concerning this particular version is that it establishes allusion to both the Catullan Ariadne and the Ovidian Ariadne of Heroides 10. However, as this article suggests, Ovid shatters the intrinsic web connecting the two pre-existing versions of Ariadne's story, de-constructs her imago and transforms her from a lamenting deserted heroine with a vox, who expresses her complaints verbally and is heard (at least by the external readers), to a deserted heroine who loses her voice and is portrayed as the victim within a rape narrative.

The de-construction of the figura of a lamenting and abandoned Ariadne within an epistolary framework and its re-imagination and subsequent re-labelling as the figura of a rape victim at Ars am. 1.527-64 is crucial because it demonstrates the major change that Ovid brings to the treatment of the specific heroine, creating an interesting variation from pre-

2 I do not consider the account in the Metamorphoses (8.171-82) as one of the main accounts for two reasons; firstly it is very brief and secondly it does not include a monologue or a speech of the heroine. However, when necessary the passage will be included in the discussion.

3 Selected studies on allusion in Latin literature in general include Conte 1986; Hinds 1998: 99-122. On Ovidian allusion see Barchiesi 2001: 79-103, 141-54. On Ovidian allusion in the Heroides in particular see Barchiesi 2001; Jolivet 2001: 193-229. On Ovid's allusion to Catullus 64 within the boundaries of Her. 10 see Armstrong 2006: 221-41. On Ovidian allusion and self-reflexive allusion at Ars am. 1.527-64 and Fast. 3.459-561 see Armstrong 2006: 241-60. 
vious representations of Ariadne (including his own portrayal of the heroine as a letter-writer). In support of this argument, not only previous treatments of the story will be taken into consideration, but also two rape narratives involving other elegiac heroines, namely the Propertian Cynthia (1.3) and the Ovidian Sabine women (Ars am. 1.89-134), ${ }^{4}$ as well as scholarly approaches of Ovidian rape narratives, addressing how and why Ovid introduces this novelty to his second treatment of Ariadne.

\section{THE RE-IMAGINATION AND THE DE-CONSTRUCTION OF ARIADNE AS A RAPE VICTIM}

Ovid's portrayal of Ariadne as a letter-writer within the boundaries of his epistolary collection involves a de-construction in his second version of the heroine. In Heroides 10, his first extant version of the story, Ariadne as the supposed letter-writer and narrator delivers a monologue that aims to convince both the internal reader (Theseus) and the external readers of her dire situation and the need for her rescue. ${ }^{5}$ The monologue, as a technique, enables the poet to focus on the heroine and her feelings in a specific temporal moment (enriched with the inclusion of past memories and worries for the future).

However, the Ars offers a better treatment of the particular story as a whole than the letter, despite the substantial reduction in length (the digression covers merely thirty-seven lines):

4 I follow the Oxford edition for Ovid (Kenney 1994) and Propertius (Heyworth 2007a); the Teubner edition for Catullus (Eisenhut 1983) and Vergil (Conte 2009). However, I use $v$ instead of $u$ and $i$ instead of $j$. For the translations of Greek and Latin texts I follow the Loeb editions, unless stated otherwise.

5 On the relationship between writer and reader in the epistolary collection see Fulkerson 2005: 23-29, who discusses the familial relationships between heroines such as Phyllis, Dido, Ariadne and Medea; Fulkerson 2005: 122-42 explores the familial relationship between Ariadne and Phaedra in particular. On Ariadne as part of a landscape of deserted heroines see Spentzou 2003: 52-56, 70. On female letter-writing in the collection see Lindheim 2003:13-77. On the male readers of Ars Amatoria 1 and 2 see Holzberg 2006: 40-49. 
Cnosis in ignotis amens errabat harenis, qua brevis aequoreis Dia feritur aquis; utque erat e somno, tunica velata recincta, nuda pedem, croceas irreligata comas, 530 Thesea crudelem surdas clamabat ad undas, indigno teneras imbre rigante genas. clamabat flebatque simul, sed utrumque decebat; non facta est lacrimis turpior illa suis. iamque iterum tundens mollissima pectora palmis 'perfidus ille abiit: quid mihi fiet?' ait; 'quid mihi fiet?' ait; sonuerunt cymbala toto litore et attonita tympana pulsa manu. excidit illa metu rupitque novissima verba; nullus in exanimi corpore sanguis erat. ecce, Mimallonides sparsis in terga capillis, ecce, leves Satyri, praevia turba dei. ebrius, ecce, senex pando Silenus asello vix sedet et pressas continet arte iubas. dum sequitur Bacchas, Bacchae fugiuntque petuntque, 545 quadrupedem ferula dum malus urget eques, in caput aurito cecidit delapsus asello;

clamarunt Satyri 'surge age, surge, pater.' iam deus in curru, quem summum texerat uvis, tigribus adiunctis aurea lora dabat. et color et Theseus et vox abiere puellae, terque fugam petiit terque retenta metu est. horruit, ut steriles, agitat quas ventus, aristae, et levis in madida canna palude tremit. cui deus 'en, adsum tibi cura fidelior' inquit;

'pone metum, Bacchi Cnosias uxor eris. munus habe caelum: caelo spectabere sidus;

saepe reget dubiam Cressa Corona ratem.' dixit et e curru, ne tigres illa timeret, desilit (imposito cessit harena pede) implicitamque sinu, neque enim pugnare valebat, abstulit: in facili est omnia posse deo. 
pars 'Hymeneae' canunt, pars clamant 'Euhion euhoe';

sic coeunt sacro nupta deusque toro.

('The Cretan maid wandered distractedly on the unknown sand, where little Dia is lashed by the sea waves. Just as she came from sleep, clad in an ungirt tunic, barefoot, with yellow hair unbound, she cried upon Theseus over the deaf waters, while an innocent shower bedewed her tender cheeks. She clamoured and wept together, but both became her; nor was she made less comely by her tears. Again she beats her soft bosom with her hands, and cries, 'He is gone, the faithless one; what will become of me?' 'What will become of me?' she cries: then o'er all the shore cymbals resounded and drums beaten by frenzied hands. She fainted for fear, and broke off her latest words; no blood was there in her lifeless frame. Lo! Bacchanals with tresses streaming behind them, lo! wanton Satyrs, the god's forerunning band; lo! drunken old Silenus scarce sits his crookbacked ass, and leaning clings to the mane before him. While he pursues the Bacchanals, and the Bacchanals flee and again attack, and while the unskilful horseman urges his beast with a rod, he falls off the long-eared ass and topples head-foremost and the Satyrs cry, 'Come, get up, father, get up!' And now on his car, that he had covered with grape-clusters, the god was giving the golden reins to his yoked tigers: voice, colour-and Theseus, all were gone from the girl; thrice she tried flight, thrice fear stayed her. She shuddered, as slender stalks are shaken by the wind, or as the light rush that trembles in the watery marsh. 'Lo, here am I', said the god to her 'a more faithful lover; have no fear, Cretan maid, thou shalt be the spouse of Bacchus. For thy gift take the sky; as a star in the sky thou shalt be gazed at; the Cretan Crown shall often guide the doubtful bark.' He spoke, and lest she should fear the tigers leapt down from the chariot; the sand gave place to his alighting foot; and clasping her to his bosom (for she had no strength to fight) he bore her away; easy is it for a god to be all-powerful. Some chant 'Hail Hymenaeus!' some shout 'Euhoe, Euhian!' So do the bride and the god meet on the sacred couch.')

The story in the Ars is divided into three parts and, unlike the letter, it covers Ariadne's present and future situation in a clear chronological or- 
der, with the first two parts creating explicit allusions to both the Catullan ecphrasis and the Ovidian letter. ${ }^{6}$ The episode begins with the introduction of Ariadne and the description of her desertion on the shores of Dia by Theseus (Ars am. 1.527-36), which reflects the first section of the letter where the heroine describes her own actions on the island after she has realised her situation (Her. 10.7-58).

Despite the differences in length, structure and perspective, a verbal and thematic sequence occurs from one account to another. Most importantly, the Ars story continues from where it stops in the Heroides. Ariadne's last words in the letter summarise and highlight the three features that reflect her lamentation, i.e. her hands (Her. 10.145-46), hair (Her. 10.147) and tears (Her. 10.150-51). The new account re-introduces all three features (Ars am. 1.530, 534, 535). The end of the first account then is alluded to thematically and verbally by the beginning of the second. Ovid leaves Ariadne weeping at Her. 10.148 (per lacrimas oro) and that is the motif he stresses at Ars am. 1.533 (clamabat flebatque simul, sed utrumque decebat 'she clamoured and wept together, but both became her'), creating a thematic and visual bridge between the two texts. The imago of a lamenting heroine on the shore becomes the connecting thread between the two Ovidian passages.

The second part is devoted to the arrival of the Maenads that interrupts Ariadne's brief speech. In this part, a description of the Maenads and of Silenus is incorporated which functions as an introduction to the god Bacchus (Ars am. 1.537-48). In the third part Bacchus himself finally appears, addresses Ariadne and offers marriage to her, thus supplying her with specific means of rescue and a clear solution to the problem faced by the abandoned heroine (Her. 1.549-64). Interestingly, her meeting with Bacchus replaces in the new account her encounter with Theseus, which is presented in the letter in the form of a digression to the past and a mnemonic recalling of the fateful meeting that leads the heroine to her static position as a deserted heroine within an epistolary setting (Her. 10.59-110). What is more, the heroine's epistolary monologue ends with her terror that she will die on the island without the proper funerary rituals, as well as with her final address to Theseus, hoping to

6 On the so-called 'double allusion' that is evident in this passage see Murgatroyd 1994. 
convince him to return for her (Her. 10.119-52). The new account provides an answer to her cries for help with the arrival of the god and cleverly stages a wedding ceremony, which replaces the funerary ritual described in the letter (Her. 10.119-24, 137-38).

It is evident that the story in the Ars has a beginning, middle and an end (or at least that is the illusion created) as it manifests a linear structure and story-line, something that does not occur in the letter. Unlike the letter, Ariadne's story in the Ars is presented as a digression narrated by the male praeceptor amoris, ${ }^{7}$ supplementing and explaining an argument in the main text, and following thus Catullus' incorporation of the heroine's story within another story in the epyllion. ${ }^{8}$ In contrast to the epistolary version of Ariadne, the narrator's perspective dominates this new account and most importantly the male character's perspective (i.e. Bacchus) is introduced for the first time in a Roman treatment of the story. ${ }^{9}$ On a first reading, this variation does not seem out of place since the god of wine and tragedy appears within the Ars Amatoria as part of the praeceptor amoris' amatory advice to his male readers. On a second reading, however, the god's appearance is attributed an importance, not

7 Ovid creates the persona of the praeceptor amoris as a means of reflecting and strengthening the didactic aspect of his new poetic endeavor. On the persona of the Ovidian praeceptor amoris see Watson 2002: 149-51; on erotodidaxis in elegy see James 2003a: 161-66.

8 On the relation between the main story and the secondary story of the ecphrasis within the Catullan passage see Armstrong 2006: 190; Warden 1998: 398-413; Deroux 1986; Duban 1980: 777-78; Putnam 1972; Kinsey 1965: 911-12. For a compelling cultural reading of Catullus 64 see Dufallo 2013: 39-73, who concludes (at p. 73): 'Poem 64 , in short, does not emerge from or produce a stable impression of image or text, past or present, Greekness or Romanness, but offers its audience an ironic and yet sympathetic perspective on a kind of cultivated play blurring these categories as they intersect with others: objecthood and subjecthood, love and heroism, the personal and political.'

9 Cf. Catull. 64.249-64. The Neoteric poet offers a description of the arrival of the god and of his entourage, that does not include a speech of the god. This omission offers a narrative opportunity that Ovid exploits successfully. The second Ovidian version re-introduces Bacchus clearly, echoing Catullus to a degree, but it develops the god's role in a more explicit manner than his model by including a brief speech by the god (Ars am. 1.555-58). 
evident in previous versions of the story or scholarly readings. As the discussion will demonstrate, the god's arrival and his very presence are crucial pieces in the construction of the rape narrative, as is the confinement of the heroine's speech to two verses (Ars am. 1.534-35), that limits significantly the importance of the female perspective in this new narrative.

Rape stories are common in Ovid's poetic corpus, especially in his later works, such as the Metamorphoses and the Fasti, and thus have attracted the attention of many scholars. Paradoxically, the Ariadne passage in the Ars is generally not considered an Ovidian rape narrative. ${ }^{10}$ In fact, previous treatments of the heroine's myth do not include the rape theme explicitly. This re-interpretation of the digression as a rape narrative was initially triggered by an argument made by Wiseman who, in his discussion of the Catullan ecphrasis, suggests that the Neoteric poet is alluding to a version of the story that indicated Bacchus' intention as being not marriage but rape at Catullus 64.253: te quaerens, Ariadna, tuoque incensus amore ('looking for you, Ariadne, and on fire with passion for you'). ${ }^{11}$ To strengthen his argument, the scholar offers as proof a comment on a painting of the god in Pausanias 1.20 .3 ('Apló $\delta v \eta \delta \dot{\varepsilon} \kappa \alpha \theta \varepsilon v ́ \delta o v \sigma \alpha \kappa \alpha i$


'Ariadne asleep, Theseus putting out to sea, and Dionysus on his arrival to carry off Ariadne'), ${ }^{12}$ where the Greek word $\alpha \rho \pi \alpha \gamma \eta$ indicates rape. ${ }^{13}$ Despite the scholar's intriguing reading of the Catullan version, there are

10 Both Murgatroyd 2000: 75 n. 2 and Richlin 1992: 166 suggest that there are only two rape stories in the Ars Amatoria: the rape of the Sabines and the tale of Achilles and Deidamia. Richlin has detected specific features that appear repeatedly in rape stories throughout the Ovidian poetic corpus. The application of her approach (although it is not as detailed as Murgatroyd's) also strengthens the argument in favour of the construction of a rape setting at Ars am. 1.527-64. Only Armstrong 2006: 24647 suggests that the parallel between Ariadne's depiction at Ars am. 1.551-54 and the Sabine women at Ars am.1.117-20 and Ars am. 1.125-26 highlights the rape theme, but she does not explore the entire episode as a rape narrative. The same applies for Blodgett 1973: 325 who casually mentions '[t]his is rape' but does not elaborate further.

11 For the translation of Catullus 64 I follow Godwin 1995.

12 Wiseman 1977: 179.

13 LSJ s.v. ó $\rho \pi \alpha \gamma \eta ́$ A. 
two main issues with this approach. On the one hand, Wiseman's approach is based on the use of a later author. None of the previous Greek accounts of the myth use the particular word when referring to Bacchus' attitude towards Ariadne. On the other hand, the Catullan text itself does not appear to create explicitly a rape setting, but rather a wedding ceremony. ${ }^{14}$ However, the same cannot be said for the Ovidian text, where the lines between salvation and victimisation are blurred.

It becomes obvious that Ovid implicitly de-constructs his previous version of Ariadne as a static figura of an abandoned heroine depicted in a letter and attributes to her new traits that are in keeping with a rape victim within the boundaries of his new poetic work. As mentioned earlier in the discussion, the god's arrival is central to this re-interpretation of the text, as it enables the male reader to envision a new storyline for Ariadne as a rape victim and it triggers what Murgatroyd considers one of the functions of a stereotypical Ovidian rape narrative. Murgatroyd has suggested a very detailed narratological approach to rape stories in the Fasti in particular, which applies as well to earlier works such as the Ars Amatoria. The scholar argues that there are twenty-six functions in the Fasti rape stories and that these functions appear in three different stages ${ }^{15}$ although these stories do not have all the functions or stages. ${ }^{16}$ The first stage includes the events before the rape, the second stage refers to the act of rape itself, whereas the third stage includes the subsequent events related to the rape. With a simple reading it becomes evident that all three stages appear during the narration of Ariadne's story in the Ars. To be more precise, out of the four functions of the first stage the one that appears is the 'arrival' of the rapist (Bacchus) at verse 549. ${ }^{17}$ However, before this divine appearance, the readers are provided with an imago of the soon to be victim at the beginning of the passage. Ariadne

14 Regarding the Catullan wedding ceremony see Forsyth 1980, who suggests that Catull. 64 constructs a marriage between Ariadne and Bacchus rather than a rape and bases his argument on verbal evidence from the poem itself.

15 Murgatroyd 2005: 67. For reasons of brevity I will mention only the functions directly applied to the specific passage.

16 Murgatroyd 2005: 67.

17 On this function see Murgatroyd 2005: 67. 
has just been awakened from sleep (utque erat e somno, 1.529), ${ }^{18}$ with her loose dress (tunica velata recincta, 1.529), bare feet (nuda pedem, 1.530) and her dishevelled blond hair (croceas irreligata comas, 1.530) creating the impression of her sexual availability and a possible consensual encounter with the god. ${ }^{19}$ What is noteworthy regarding this description of Ariadne is that it echoes the description of Corinna at Am. 1.5.9 with the repetition of the phrase tunica velata recincta. This is intriguing for the re-interpretation of the Ovidian Ariadne; Amores 1.5 is one of two examples of elegies - along with Prop. 2.15 - describing a successful sexual encounter between the amator and his puella. ${ }^{20}$ By connecting the two passages with

18 On the importance of somnus (combined, however, with wine) in Ovidian rape narratives see Hejduk 2011: 21, whose discussion focuses on rape narratives in Fasti book 2.

19 The reference to blond hair seems to foreshadow Ariadne's marital status since it is often used within the context of marriage. Cf. Hollis 1977: 122 on Ov. Ars am. 1.530, who suggests that it alludes to the $\xi \alpha v \theta \eta \dot{v}$ 'A 242 n. 49 explains that the adjective croceas of hair is used only by Ovid, while none of his predecessors uses it. It occurs 7 times in Ovid, of which it is used to characterise hair only here and Ov. Am. 2.4.43.

20 Cf. Ov. Am. 1.5.9: ecce, Corinna venit, tunica velata recincta ('Io, Corinna comes, draped in tunic girded round'). McKeown 1989: 110 ad loc. notes the verbal repetition of the phrase tunica velata recincta at Ars am. 1.529 (during the portrayal of a deserted by Theseus Ariadne) and Fast. 3.645 (where a fleeing and victimised Anna, whose flight is triggered by the appearance of Dido's ghost, is finally deified and becomes Anna Perenna). See Ov. Fast. 3.645-46: cumque metu rapitur tunica velata recincta, / currit ut auditis territa damma lupis ('and as soon as terror carried her, clad in her ungirt tunic, she ran as runs a frightened doe that hears the wolves'). At Ov. Am. 1.5 the poet not only names his puella for the first time, but he also offers a detailed description of Corinna (with a focus on her body at Am.1.5.19-21) before the successful sexual encounter. Cf. Ovid's use of the adjective nuda for both Corinna and Ariadne at Ov. Am. 1.5.24: et nudam pressi corpus ad usque meum ('and I clasped her undraped form to mine'). Also cf. an interesting use of the same adjective at Ov. Met. 5.602-3: [...] tanto magis instat et ardet, / et, quia nuda fui, sum visa paratior illi ('So much more he pressed on and burned with love; naked I seemed readier to his taking'). In particular, the naked Arethusa flees from her rapist and, thus, is portrayed as 'a rare heroine, defeater of a rape attempt', as characterised by Anderson 1996: 557. Contrary to Ariadne, the heroine herself, Arethusa, is the one offering the visual and emotional portrait. What is even more intriguing is that she explicitly connects her nudity with male desire and in fact uses the former as an explanation for the latter. It becomes 
the imagery of a loose tunic and dishevelled hair, ${ }^{21}$ Ovid attributes a distinctive sexual availability to Ariadne, suitable for a puella within an amatory work.

This display of the woman's body preceding the rape appears often in these narratives. ${ }^{22}$ In the Ars passage, the description of the heroine's figura justifies her victimisation under the male gaze of the god and of the reader(s), a gaze that dominates the text. Ariadne's perspective is nonexistent at this point of the narrative and the readers are to assume that her gaze is distorted, hence the inclusion of somnus. The lamenting heroine has just woken up; she is still under the influence of sleep and her mind is in a state of haze, meaning that what she sees and what she perceives as real could simply be a figment of her post-sleep confusion and imagination - or at least that is the illusion created by the praeceptor amoris.

Because of the sleep-induced haziness, Ariadne's reaction to the god's arrival echoes another main feature of an Ovidian rape scene - the combination of fear and flight: ${ }^{23}$ Ariadne's fear upon seeing the god is com-

evident that nudity, within the context of these passages, indicates the objectification and victimisation of these heroines.

21 On the erotic connotations of the loose tunic at Ov. Am.1.5.13-14 cf. McKeown 1989: 113-14 ad loc. Regarding women's loose hair in love-scenes see Bömer 1958: 135-36 on Ov. Fast. 2.772.

22 Richlin 1992: 162.

23 Richlin 1992: 162. The scholar offers a few exempla of fleeing rape victims from the Metamorphoses and the Fasti, such as Daphne fleeing from Apollo. See Ov. Met. 1.52530: plura locuturum timido Peneia cursu / fugit cumque ipso verba imperfecta reliquit, / tum quoque visa decens; nudabant corpora venti, / obviaque adversas vibrabant flamina vestes, / et levis impulsos retro dabat aura capillos, / auctaque forma fuga est. ('He would have said more, but the maiden pursued her frightened way and left him with his words unfinished, even in her desertion seeming fair. The winds bared her limbs, the opposing breezes set her garments aflutter as she ran, and a light air flung her locks streaming behind her. Her beauty was enhanced by flight.') Leucothoe is portrayed as fearful during the rape at Ov. Met. 4.230-33: ipse timor decuit, nec longius ille moratus / in veram rediit speciem solitumque nitorem; / at virgo quamvis inopino territa visu / victa nitore dei posita vim passa querella est. ('Her very fear becomes her. Then he, no longer tarrying, resumes his own form and his wonted splendour. But the maiden, though in terror at this sudden apparition, yet, overwhelmed by his radiance, at last without protest 
bined with an unsuccessful attempt to flee (terque fugam petit, terque retenta metu est 'thrice did she essay flight, thrice did fear restrain her', Ars am. 1.552). The concept of fear triggering an endeavour to escape vividly recalls rape stories narrated by Ovid at a later stage of his career. ${ }^{24}$ What is more, the use of similes constitutes another feature of Ovidian rape narratives. ${ }^{25}$ In the passage in question, the simile creates the imago of Ariadne shaking, a reaction triggered by her fearful state (Ars am. 1.55354). The choice of verbs (horruit and tremit) illuminates the heroine's new fear of a possible rape. ${ }^{26}$

From the second stage, then, of a stereotypical Ovidian rape narrative three out of ten functions are evident in the episode: the 'flight' of the victim (in this case unsuccessful) at verse 552 that is followed by the rapist's attempt to reassure and 'calm' the victim at verse 556 (pone metum

suffers the ardent wooing of the god.') Europa's fear is the cause of new beauty at Ov. Fast. 5.608: et timor ipse novi causa decoris erat ('and her very fear lent her fresh grace'). Additionally, Lucretia is the victim of her rapist's gaze at Ov. Fast. 2.757-58: hoc ipsum decuit: lacrimae decuere pudicam, / et facies animo dignaque parque fuit. ('The gesture was becoming; becoming, too, her modest tears; her face was worthy of its peer, her soul.') See Robinson 2011: 479 on Ov. Fast. 2.757, who underlines the verbal and thematic similarity with Ov. Ars am. 1.533.

24 Ov. Ars am. 1.553-54: horruit, ut steriles, agitat quas ventus, aristae, / ut levis in madida canna palude tremit. ('She shuddered, as when dry stalks are shaken by the wind, as when the light rush trembles in the watery marsh.')

25 Murgatroyd 2000: 81. Additionally, similes are interconnected in the Metamorphoses with transformation and function as a prelude of the metamorphosis itself, which creates an implicit connection with its equivalent function in the specific passage from the Ars. See Von Glinsky 2012: 7-15 on the association between metamorphosis and simile.

26 Cf. the equivalent verbs at Her. 10.139-40 (horret and tremente). In the letter the heroine herself offers another simile to highlight her fear and subsequent trembling, ten lines before the end of the letter, where the letter-writer constructs a different kind of setting (namely a funereal setting). The simile within the Ars has a clear allusive purpose, as it underlines Ovid's authorial self-awareness by inserting a simile that echoes verbally his previous treatment. However, the two similes function in a different manner within the context of each text; in the letter, the simile functions as means of a vivid description of the heroine's fear of death, whereas in the Ars, the simile functions as a means of emphasising the heroine's fear of a possible rape. Also see Battistella 2010: 104 ad loc. who notes that trembling is characteristic of only one other letter-writer, Canace (as she awaits her father's arrival) at Ov. Her. 11.75-79. 
says Bacchus to Ariadne) ${ }^{27}$ as well as the implied rape at verse 561 with the use of pugnare. ${ }^{28}$ The implication and the creation of subtle rape imagery are common in Ovid, as his rape narratives are not explicit. ${ }^{29}$

The victimisation of the heroine is highlighted further with the explicit 'recompense' offered to her. In general in later Ovidian rape narratives (especially in the Metamorphoses) the act of rape is often followed by a transformation of the rape victim, which is usually presented as punishment. ${ }^{30}$ However, in this passage 'recompense' and not 'punishment' is offered to the heroine, which again is not unusual; 'recompense' in the form of both marriage and a gift at verses 556-58 is one function (out of the 11 mentioned by Murgatroyd) that appears in the third stage of a typical Ovidian rape narrative. ${ }^{31}$ The god promises that the heroine will

27 The exact phrase pone metum is repeated in the narration of Lucretia's rape at Ov. Fast. 2.759: 'pone metum, venil' coniunx ait [...] ('Fear not, I've come' her husband said'), although it is associated with her husband, not her rapist. See Robinson 2011: 480 ad loc. on Lucretia's behaviour that deviates from the ethos of the 'dignified Roman matron' and resembles the behaviour of the elegiac puella.

28 On these functions see Murgatroyd 2005: 68. Also cf. the double use of the verb at Ov. Am. 1.5.14-15 (pugnabat/pugnaret): the poet describes Corinna's (unsuccessful) attempt to cover herself with her loose tunic. Cf. McKeown 1989: 114 on Ov. Am. 1.5.14, who notes the erotic connotations of the verb not only in these lines, but also at Ov. Ars am. 1.561, as well as its association with the militia amoris motif; as he suggests Corinna resembles 'a city under siege'. On the sexual connotations of the verb see also Adams 1982: 147.

29 On this subject see Richlin 1992: 162-63, who explains that this lack of explicit rape imagery is substituted by Ovid's depiction of violence within the rape narratives and offers Philomela's story as a convincing example (Ov. Met. 6.424-674). Philomela's rape story is infamous for the brutality and violence inflicted upon the victim. The heroine loses her tongue (literally) and subsequently her ability to verbally recollect the assault inflicted upon her (Ov. Met. 6.555-60). For a detailed discussion of speech and victimisation in Ovid see Fulkerson 2016: 66-72 who discusses exempla of speech that prove 'dangerous' for its speaker. Amongst the examples, she lists rape victims from the Metamorphoses and the Fasti. The scholar (in p. 73) also notes that 'readers of Ovid cannot help but notice that women are a primary category of those victimised within the poetry'.

30 Richlin 1992: 165.

31 On this function see Murgatroyd 2005: 68. Regarding the technical matters of rape narratives, an Ovidian rape narrative should cover a passage of minimum ten verses and have at least three functions and two stages, according to Murgatroyd 2000: 75. 
be transformed into a star, after he announces that she will become his wife (Ars am. 1.556-57). Contrary to the Catullan characterisation of Bacchus as incensus amore (Catull. 64.253), Ovid does not explicitly mention Bacchus' love for Ariadne. The story begins with the justification of the god's favouring of amantes (Ars am. 1.525-26): he too feels the flames of love, or is it lust? But Ariadne is not amans; she is amens (Ars am. 1.527), a word that encompasses the combined emotion of amatory frenzy. ${ }^{32}$ The obvious Ovidian wordplay purposefully creates the image of an emotional heroine, out of control, whose reactions cannot be trusted. Simultaneously, the focus on male perspective is magnified: the readers perceive Ariadne in a manner that is suitable for the text. Ariadne is out of control, whereas the god is in control. Hence, he is inserted into the narrative and offers marriage and transformation to the heroine. The god's speech has a dual function: on the one hand, it establishes his role in her rescue and, on the other hand, strengthens the argument that the gifts

The Ariadne narrative evidently fulfils all three criteria: it covers more than ten verses; it has five functions and three stages. It is clear, then, that this new version of Ariadne's story displays the features of a typical rape narrative as it is staged in Ovid's later works, which indicates that the poet's approach to rape stories is identical throughout his works, despite the chronological gap between them.

32 Murgatroyd 1994: 89 suggests that Ovid alludes to Catullus by highlighting Ariadne's mental state. He argues that the word amens may be linked with various verses in Catullus, e.g. 64.54: indomitos in corde gerens Ariadna furores ('Ariadne watches bearing uncontrolled madness in her heart'); 64.124: saepe illam perhibent ardenti corde furentem ('often, they say, she was raging with a blazing heart'); 64.165: externata malo, quae nullis sensibus auctae ('out of my mind with sorrow speaking to winds which are endowed with no senses'); 64.197: cogor inops, ardens, amenti caeca furore ('helpless, blazing, blind with mindless madness'). On Ariadne's frenzy in Ovid see also Morrison 1992, who argues that the heroine's portrayal at Ov. Am. 1.7.15-6 alludes to four instances of frenzy at Catull. 64.53-54, 94-95, 124, 192-97. It is clear then that Ovid's treatment (in both poems) is influenced by Catullus. The problem is whether Ovid is simply alluding to Catullus and varying his version, as Murgatroyd suggests, or this characterisation of the heroine has a new role to play in the new account. Cf. Ariadne's new status at Ov. Fast. 3.469-70: flebat amans coniunx spatiataque litore curvo / edidit incultis talia verba comis. ('His loving spouse wept and pacing the winding shore with dishevelled locks she uttered these words.') On the Fasti version as a 'direct continuation' of the Ars version see Harries 1989: 181; on its mnemonic allusions see Armstrong 2006: 48-50. 
are a double retribution for the rape..$^{33}$ Marriage functions, then, as a form of recompense within an Ovidian rape narrative, which explains its presence in the passage. ${ }^{34}$

\section{THE METAMORPHOSIS OF A LAMENTING HEROINE: A PRELUDE TO TRANSFORMATION STORIES}

Once we acknowledge the re-interpretation of this passage as an Ovidian rape story, then it is possible to detect another parallel with the subsequent rape stories, that of the connection with aetiology. The rape stories in the Fasti function as means to offer aetia, a role that the Ariadne story has as well. ${ }^{35}$ The aetiological aspect of Ovidian rape narrative is also evident in the Ars version of Ariadne, which presents an aetion associated with a dual transformation, creating a prelude of the transformation stories of the Metamorphoses. ${ }^{36}$

33 The praeceptor amoris offers various advices to his students and readers, including the offering of gifts to the puella, such as fruit etc. (cf. Ov. Ars am. 2.261-70). He also mentions that gifts are expected by the puella on special occasions, such as birthdays (cf. Ov. Ars am. 1.417-20). In the Ariadne episode, Bacchus offers significant gifts, which indicates that his gift giving is not simply following the instructions of the praeceptor amoris. For an overview of the attitude and instructions of the praeceptor amoris in the Ars see James 2003a: 198-209. On the work's ‘problematic narrator' see Fulkerson 2016: 40.

34 Cf. Ov. Ars am. 1.564: sic coeunt sacro nupta deusque toro ('so do the bride and the god meet on the sacred couch'). The reference to the marital union between the god and the heroine on a first reading seems to contradict this opinion. The marriage imagery initially appears to break the illusion of the rape setting, as it creates an inconsistency within the narrative. However, marriage often functions as recompense for rape, as it is indicated by Murgatroyd 2005: 68 .

35 Murgatroyd 2000: 84-86 explains that these rape narratives sometimes begin with a concern for origins, thus they are connected with aetiology. What is more, their endings usually involve aetiology, reversal of fortune, a new status (amongst others). In the Ariadne episode, these elements appear clearly.

36 As Richlin 1992: 162 highlights the rape narratives of the Metamorphoses are often associated with twisted versions of love, death, divine punishment, nature, wars and transformation itself, whereas in the Fasti they are interwoven with the aetiology of the Roman religious calendar. 
The re-imagination and transformation of the heroine's status is further highlighted with the explicit incorporation of the theme of catasterism, which is attested already in the Greek literary tradition. It appears in four Greek accounts, prior to Ovid; Pherecydes' account in the scholia on the Odyssey 11.322, in Eratosthenes' Catasterismi 5, in Aratus' Phaenomena 71-73 and in Apollonius Rhodius' Argonautica 3.997-1004. A brief overview of the sources on the catasterism reveals one variant element of Ovid's account: the image of Ariadne being transformed into a star and not her crown. All the surviving sources (three of which are Hellenistic) name the crown as the transformed star, none names Ariadne. ${ }^{37}$ Only in Ovid is the heroine herself said to be transformed into the star (caelo spectabere sidus, Ars am. 1.557). This differentiation by no means implies that Ovid is not aware of the well-known story of the crown's transformation. On the contrary, the poet's awareness of the catasterism of the crown is suggested by its inclusion in his later re-writings of the Ariadne mythos at Met. 8.174-82 and Fast. 3.459-516. ${ }^{38}$ The name given to the star (Cressa Corona, Ars am. 1.558) is proof of his familiarity with this detail regarding the catasterism already in the Ars, whereas Ovid's use of the noun corona at Met. 8.178 and Fast. 3.513 suggests that he perceives the crown's catasterism as an established feature of the tale. Thus, the poet includes two types of transformation in his treatment: both the heroine and the crown are transformed. The former, which is mentioned first, is Ovid's variation of the story, whereas the latter provides the opportunity to establish allusion to the preceding Greek treatment of Ariadne.

37 For a concise discussion of the pre-Ovidian sources of the catasterism see Armstrong 2006: 312-15.

38 Ov. Met. 8.176-79: [...] desertae et multa querenti / amplexus et opem Liber tulit, utque perenni / sidere clara foret, sumptam de fronte coronam/immisit caelo; tenues volat illa per auras. ('To the deserted and much complaining girl Liber brought caresses and help, and, that she might be famous with her own fixed star, he took the crown from her forehead and set it up in the sky', transl. Hill 1992.) Ov. Fast. 3.513-16: sintque tuae tecum faciam monumenta coronae, / Volcanus Veneri quam dedit, illa tibi.' / dicta facit, gemmasque novem transformat in ignes: / aurea per stellas nunc micat illa novem. ('and I will see to it that with you there shall be a memorial of your crown, that crown which Vulcan gave to Venus, and she to you.' He did as he had said and changed the nine jewels of her crown into fires. Now the golden crown shall sparkle with nine stars.') 
It is interesting that Ovid offers a narrative that leads not only to the transformation of the crown to a star, but also to the transformation of the heroine. One plausible and reasonable interpretation is the one given by Hollis, ${ }^{39}$ who argues that Ovid is including in the Ars episode a rare account attested in Propertius which presents Ariadne elevated and transformed into a star at 3.17.7-8: te quoque enim non esse rudem testatur in astris / lyncibus ad caelum vecta Ariadna tuis ('for you are not without experience: to that, carried by your lynx-drawn chariot to heaven, Ariadne bears witness among the stars'). ${ }^{40}$ But, it is not simply a matter of alluding to another source that presents another kind of catasterism and transformation. Ovid clearly favours an obscure account of the catasterism, instead of the popular version. He has already succeeded in differentiating his version from the Catullan ecphrasis, as the latter does not mention the catasterism at all. So, the question still remains as such: why incorporate the heroine's catasterism?

The answer can be found in the re-imagination of the letter-writer and her portrayal as a rape victim. This new Ovidian version of Ariadne differs both from his own previous version of Ariadne as a letter-writer and from the Catullan Ariadne as the speaking figura of an ecphrasis by embedding one element of the story that does not exist and is not even implied in either of them. The transformation of the heroine functions as a recompense for the rape, just like the offer of marriage. The heroine's transformation (by being an obscure feature of the myth) would immediately draw the readers' attention, offering a new perspective on Ariadne.

Transformation is the feature of the myth highlighted at the end of this passage. The act of metamorphosis itself is triggered by a deity, and it focuses on the external appearance of a hero or a heroine; his or her imago. As indicated by Ariadne the letter-writer, the emotion of fear, present in her first Ovidian portrayal, is interlinked with the appearance of

39 Hollis 1977: 124 on Ov. Ars am. 1.557-58.

40 Cf. Heyworth 2007a: 134 who prints amoris instead of in astris at Prop. 3.17.7; 2007b: 375 ad loc. suggests that these Propertian lines justify the poet's 'belief that the god should be sympathetic to the lover'. The same notion is echoed by the Ovidian inclusion of the god in the Ars. 
gods; Ariadne establishes this fear at verse 95 of her letter (caelum restabat: timeo simulacra deorum 'the sky remains - yet there I fear visions of the gods'). ${ }^{41}$ The word simulacrum is the Latin equivalent for the Greek word $\varepsilon 1 \delta \omega \lambda$ ov, ${ }^{42}$ which indicates that its use alludes possibly to the concept of catasterism, already from the Ovidian epistle, where there is no other function other than allusion to previous versions of the story. However, the new version establishes another function: Ariadne has been fearful of the simulacra deorum for a valid reason; the god's appearance will trigger a new narrative. As the victim of a rape narrative she will be forced to undergo a transformation of her own imago.

41 There are numerous interpretations of this epistolary line. Knox 1995: 250 on Ov. Her. 10.95 suggests that the phrase means 'images of the gods', particularly those in temples, and that the heroine's crime against her family creates her fear of gods. Both Barchiesi 2001: 23 and Volk 2003: 349 agree that the phrase simulacra deorum indicates Ariadne's fear of divine punishment. What is more, Barchiesi 2001: 23 underlines the triple meaning of the word simulacra (i.e. ghosts, statues of gods and constellations) and suggests that it foreshadows the constellation in the Ars and the deification in the Fasti. See for the latter Barchiesi 2001: 25 and 168 n. 39. Battistella 2010: 86 ad loc. indicates the repetition of the phrase timere simulacra that first appears at Ov. Am. 1.6.9. Interestingly, in the Amores passage the poet as the exclusus amator attempts to gain access to his puella, by addressing the persona who he considers as the main obstacle, the ianitor. Regarding the interpretation of the noun simulacra see Ryan \& Perkins 2011: 69 ad loc., who comment that it recalls 'descriptions of visits to the Underworld, and this is especially humorous when we realise that this 'underworld' consists of nocturnal visits to his beloved.'

42 OLD s.v. simulacrum 2.c. Cf. the use of the Greek word हi' $\delta \omega \lambda$ ov at Aratus Phaen. 71-73:

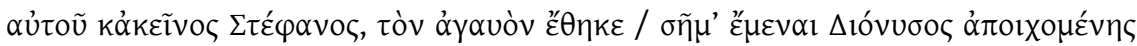

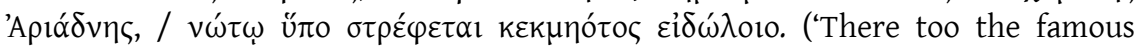
Crown, which Dionysus established to be an illustrious memorial to the departed Ariadne, circles close to the back of the labouring figure', transl. Kidd 1997: 79.) Ap.

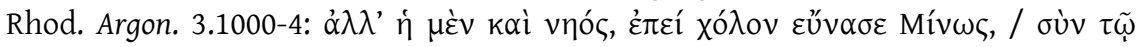

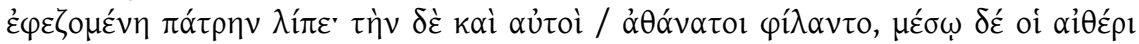

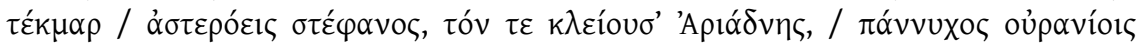

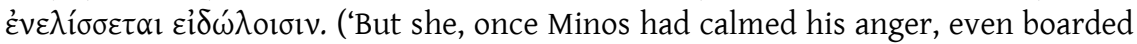
his ship with him and left her country; and even the immortals themselves loved her, and in the midst of the sky her sign, a crown of stars they call Ariadne's, turns all night among the heavenly constellations.') 
Out of the other features that function as signs of an Ovidian rape narrative, one deserves further discussion: the loss of voice creates the impression that it functions simply as a means of allusion to previous portrayals of Ariadne, but in fact establishes a common characteristic of an Ovidian heroine within a rape narrative. Fear is connected with loss of voice, especially while the woman in danger is wandering on shore, which is considered a common rape setting. ${ }^{43}$ of course the most famous wandering heroine, Ariadne, is more than suitable to acquire and adapt to this new role. Ovid constructs the rape setting clearly: Ariadne is depicted wandering on shore (Ars am.1.527), whereas the sight of Bacchus causes the heroine's loss of voice (vox abiere puellae, Ars am. 1.551).

According to the narrator, the heroine's fear leads her to faint, thus ending her speech (Ars am. 1.539). This sudden interruption of her speech deprives the heroine of control over the story. Ovid plays with the idea that without Ariadne's voice manipulating the readers to see the story from her perspective the heroine has no narrative control over the text, which creates a playful, yet antithetical allusion to the Ovidian letter. The juxtaposition with Ariadne's previous speech in the Heroides is established with the phrase novissima verba that is inserted by Ovid as a remark concerning the epistolary monologue. The monologue creates the impression that the end of Ariadne's letter signifies an end to her status as a speaking heroine. The phrase novissima verba indicates not simply the 'final' words, but it could also mean 'the last [words] before one's death'. ${ }^{44}$ This association of the phrase with death is already evident in Vergil, who employs a similar phrase for Dido's final words: incubuitque toro dixitque novissima verba ('she threw herself on the couch and spoke her last words', Verg. Aen. 4.650). ${ }^{45}$ Ovid's use of this Vergilian phrase, combined with the use of the verb errabat at Ars am. 1.527 (clearly echoing Aen. 6.451), establishes the allusion to the Vergilian Dido's novissima verba. ${ }^{46}$

43 Richlin 1992: 165.

44 OLD s.v. novissimus 2 and 3. Armstrong 2006: 245 argues that 'the words here [Ars am. 1.539-40] suggest an ending to the episode, even death, and certainly an end to speech'.

45 Armstrong 2006: 245 n. 57.

$46 \mathrm{Cf}$. the Ovidian's Dido variation of and wordplay on novissima verba at the beginning of her letter at Her. 7.6: cum male perdiderim, perdere verba leve est. ('after wretched 
The poet implies a connection between his version of Ariadne and Vergil's Dido to create certain expectations; as the praeceptor amoris he guides his readers and moulds their interpretation of Ariadne. Any educated reader would immediately recognise the dialogue with the Vergilian epic and would naturally assume that the heroine is about to face an ending, echoing Dido's fate. Initially, the Ovidian illusion established through this explicit verbal recalling of Dido is that a tragic deadly end awaits Ariadne as well. But, the readers are aware that the Roman version of the myth, established by the Catullan ecphrasis, has a happy ending. Intriguingly, in the Ovidian version not only are the lines between happy and un-happy ending blurred, but they do not put forth a definitive answer: Ariadne, as the readers are told at the end of the digression, escapes death in the literal sense and is gifted with marriage and catasterism (Ars am. 1.557-58; 1.563-64). Under the gaze of the male readers, the picture created is a happy one: the divine epiphany brings salvation to Ariadne. Unfortunately for her, salvation comes with a price that rape victims within an Ovidian text seem to share: the deprivation of voice that is illuminated with the heroine's transformation into a star.

The end to Ariadne's story, as readers know from previous versions, is highlighted even further with the Ovidian selection of vocabulary. Before the god's appearance, the use of specific verbs creates the appropriate foreshadowing of an imminent rape, although the chosen language does not appear on first reading to have erotic connotations. The combination of the verb surge at 548 with pugnare at 561 (with the former having clear sexual connotations as the male Satyrs urge Bacchus to 'get $\left.u^{\prime}\right)^{47}$ constructs an intense erotic setting that creates expectations

losing, the losing of words is a matter slight indeed.') Also cf. the association between death and the ending of her letter at Her. 7.111-12: Durat in extremum vitaeque novissima nostrae / prosequitur fati, qui fuit ante, tenor ('The lot that was mine in days past still follows me in these last moments of life and will pursue to the end'). Interestingly, the Ovidian Dido establishes her status as Aeneas' wife (coniunx at 7.113). On Ovid's re-interpretation of Dido and allusion to the Vergilian model see Miller 2004: 57-62. On the echoes between the Ovidian Ariadne and the Vergilian Dido see Battistella 2010: 28-29.

47 OLD s.v. surgo 1.d. 'to become erect'. Interestingly the OLD offers an example from Ovid regarding 'the sexual parts'. Cf. Ov. Am. 2.15.25-26: sed puto, te nuda mea membra libidine surgent, / et peragam partes anulus ille viri ('but methinks my passions would 
within a work like the Ars. ${ }^{48}$ The imagery created especially with the description of the dishevelled Maenads (Ars am. 1.541), the out-of-control crowd of Satyrs (Ars am. 1.542) and drunken Silenus (Ars am. 1.543) introduces the erotic element explicitly, adding to it a humorous tone. Silenus' unsuccessful pursuit of the Maenads (Ars am.1.545) foreshadows the god's pursuit of Ariadne and attempts to lighten the tone of the passage, ${ }^{49}$ although Bacchus' attempt, unlike Silenus', is successful. As the praeceptor amoris, towards the end of the digression, makes a remark concerning divine power: [...] in facili est omnia posse deo 'easy is it for a god to be allpowerful' (Ars am. 1.562). The antithesis between the two attempts is another feature of Ovidian rape narrative: ${ }^{50}$ the successful, yet implicit, rape of the heroine is juxtaposed to the unsuccessful attempt against the Bacchants. The power-play dynamics are clearly in favour of the omnipotent god.

Yet, the abrupt ending to the heroine's speech is indicated not only by the phrase rupitque novissima verba (Ars am. 1.539), but also in the actual interruption of Ariadne's speech by the noise created from the cymbals announcing the god's imminent arrival: 'quid mihi fiet' ait; sonuerunt cymbala toto / litore [...] ('What will become of me?' she cries: then o'er all the shore cymbals resounded', Ars am. 1.537-38). Finally, the heroine's fear is stated explicitly with excidit illa metu (Ars am. 1.539), which echoes

rise at sight of your fairness, and I, though naught but that ring, would play the human part'). This specific elegy focuses significantly on the erotic aspect of the amator's relationship with his puella. Ovid offers Corinna a gift and specifically a ring that is considered a common amatory gift by the Romans. In the Amores passage it is attributed phallic connotations. Regarding the erotic connotations of membra, libido, surgo see Adams 1982: 46 and 57.

48 The verb rumpo, in addition to its earlier interpretation, has the meaning of 'penetrate', which could be used within erotic connotations. See OLD s.v. rumpo 3.a. On the sexual connotations of the verb see Adams 1982: 151. Although the verb is not attributed to the male god and it does not appear to have clear erotic connotations in this passage, its inclusion foreshadows implicitly the violent setting of the rest of the passage, as it follows after the noun metus at 539 .

49 Hollis 1977: 123 on Ov. Ars am. 1.545: '[...] presumably the Bacchae provoke Silenus by running towards him and then away'.

50 Murgatroyd 2000: 79 offers examples from the Fasti of successful rapes contrasted or foreshadowed by unsuccessful rapes. 
a similar phrase in the letter excussere metus somnum (Her. 10.13). However, a variation occurs. In the Ars fear paralyses Ariadne and deprives her of the ability to speak, whereas in the Heroides fear awakens her and makes her active. The difference lies in the source of her fear in each text. In the former, the heroine's fear derives from the presence of new characters. In the latter, Ariadne's fear emerges due to the absence of her lover. What is more, by echoing the same phrase, Ovid underlines that the change in perspective - from the female perspective of a letterwriter to the male perspective of the praeceptor amoris - has affected the narrative as well.

Additionally, this absence of the female vox - originating in fear - echoes the portrayal of the Ovidian puella. Once again, Ariadne's depiction reflects Corinna's reaction to Ovid's violent behaviour towards her at Am. $1.7,{ }^{51}$ a similarity which stresses the former's depiction as an elegiac puella in danger. The parallels between the puella of the Amores and one of the puellae of the Ars are drawn already from Am.1.7.15-16, where the elegiac poet compares Corinna to Ariadne, focusing on the dishevelled imago of the mythological heroine. ${ }^{52}$ A few lines later, Corinna is left speechless from fear: ipsa nihil: pavido est lingua retenta metu ('Herself said

51 Armstrong 2006: 243 also stresses the element of violence which connects the Ars episode with Ov. Am. 1.7. However, she focuses mainly on the attribution of amens to both Ariadne (Ov. Ars am. 1.527) and Corinna (Ov. Am. 1.7.51). For an analysis of the function of violence in the portrayal of the elegiac puella in general see Fredrick 1998. On women and violence in the Amores see Greene 1998: 67-92 and in particular pp. 84-91 for Ov. Am. 1.7. In fact, the scholar comments (in p. 87) that these women of myth, despite their sufferings, are 'seen as beautiful objects of desire, and on top of that, they receive fama as a result of their liaisons with men who abuse and/or degrade them', thus justifying the violence inflicted upon them. On violence in Ovidian rape narratives see Johnson 1996, who suggests that Callisto's story in the Metamorphoses and the Fasti is in fact another rape narrative. Also see Richlin 1992: 168, who suggests that 'a poet who sees love as comparable to battle might well see violence as part of love.'

52 Cf. Ov. Am. 1.7.15-16: talis periuri promissaque velaque Thesei / flevit praecipites Cressa tulisse Notos ('such the Cretan maid as she wept that the headlong winds of the south had borne away both sails and promises of perjured Theseus'). On the comic undertone of this poem and its allusion to New Comedy see McKeown 1989: 162. On the comparison of Corinna to three distinctive women of myth (Atalanta at lines 13-14, Ariadne at lines 15-16, Cassandra at lines 17-18) see McKeown 1989: 171-75 ad loc. 
naught; her tongue was kept from it by trembling fear', Am. 1.7.20). Thus, a pattern emerges: an Ovidian puella in danger has no voice and is dominated by fear.

It has become evident that, within the context of the Ars, both the loss of voice and the display of fear are signs of a rape setting because they are combined with features of such a setting. Ovid demonstrates how the re-introduction of the same language and imagery can be attributed a completely different function in order to fit the generic requirements of the Ars. Although, the poet is employing the same vocabulary and constructing the same visual imago, the identity of the heroine has been transformed; the elegiac lamenting puella within an epistolary collection has become the elegiac lamenting puella within a rape narrative.

\section{ORIGINS AND PARALLELS OF OVIDIAN RAPE NARRA- TIVES: ARIADNE, CYNTHIA AND THE SABINE WOMEN}

As the discussion has demonstrated, Ovid creates at Ars am. 1.527-64 an early form of the scene of the rape of a heroine by a god and the subsequent transformation, which is perfected later in the Metamorphoses. What remains to be addressed is the function of such a narrative within the boundaries of a didactic-amatory work that breaks away from the simple elegiac representation of love and teaches how the male (in the first two books) can remain in control of the situation or at least appear to be in control..$^{53}$

Despite the differentiation from his fellow elegists, Ovid's work is obviously informed by the elegies of his predecessors, especially by the

53 Watson 2002: 148 explains briefly this change occurring in the Ars compared to earlier elegy. Also see Harrison 2002: 82-84 for a brief discussion of the changes occurring from the Heroides to the Ars Amatoria to the Remedia amoris in terms of genre; James 2003b: 101-2 who suggests that the Ars 'constitutes Ovid's commentary on Roman love elegy' and that 'the male-female relations of the Ars [...] constitute a continuation, perhaps even a completion, of the male-female relations of elegy'. For a discussion of the different perspectives (male and female) as they are explored in the three books of the Ars Amatoria see Rimell 2006: 70-103. 
Propertian elegies. ${ }^{54}$ For the purposes of this discussion, Propertius' elegy 1.3 is attributed a significant role since it is acknowledged that the pattern of the comic unsuccessful rape appears in the Propertian passage in the same way it is presented by Ovid in the Fasti rapes..$^{55}$ In a manner, Propertius is Ovid's model for rape narratives within the boundaries of works such as the Ars and the Fasti, works that have clear generic affinities. As mentioned earlier in the discussion, the Fasti rape stories can provide insight into how Ovid treated the theme, both in his earlier and in his later works. The main trait of such scenes is their consistency, despite their incorporation into different works. Once we take into consideration that Ovid uses the aforementioned Propertian elegy as a model for later rape narratives, then it is more than plausible that he uses it as a model for at least some of his earlier rape narratives.

In this Propertian elegy, the poet admits that he has been drinking and that he is seized by both Amor and Liber. ${ }^{56}$ The connection of Liber and Amor is echoed by Ovid at the beginning of the Ariadne passage (Liber ... amantes, Ars am. 1.525); Bacchus himself has fallen in love (thus the link with Amor) and for that reason he assists lovers in symposiums (hence the connection with drunkenness). Lyne offers a very intriguing interpretation of the Propertian verse, as he suggests that the verse hac Amor hac Liber, durus uterque deus (Prop. 1.3.14) underlines the poet's temptation to rape, which is overwhelmed by his fear of Cynthia's reaction and is replaced by his decision to offer her munera (Prop. 1.3.26), ${ }^{57}$ just like

54 On the immense impact and influence of Propertian poetics in Ovid's Amores in particular see Morgan 1977; Weiden Boyd 1997: 19-48. On the relation between Propertius and Ovid's Ars Amatoria see Gibson 2007.

55 Tatham 2000: 51. Also Tatham 2000: 49 suggests in her study of Prop. 1.3 that the function of such a situation (rape setting) is to create a comic outcome, if we take into account that in the context of comic plays, such as Terence's Eunuch, the staging of the rape of a sleeping girl has a comic effect.

56 Prop. 1.3.9: ebria cum multo traherem vestigia Baccho ('when home I came dragging footsteps unsteadied by much wine'); Prop. 1.3.14: hac Amor hac Liber, durus uterque deus ('for the two inexorable gods, on this side Love, on that Bacchus').

57 Lyne 2007: 5. The general scholarly interpretation of this Propertian line has not only erotic connotations, but - more importantly - suggests rape. Harrison 1994: 21 highlights the erotic connotations of durus and reminds us that the image of a Maenad by a river is that of a possible rape victim. Furthermore, Harrison 1994: 19 identifies 
Bacchus offers gifts to Ariadne (munus, Ars am. 1.557). Of course, there is one notable difference: the former's gifts are apples (Prop. 1.3.24), while the latter's are a wedding and a transformation (uxor eris, Ars am. 1.556; caelo spectabere sidus, Ars am. 1.557).

Since rape is not a theme that appears in Ariadne's myth explicitly before Ovid, it is evident that the poet has been influenced by Prop. 1.3: a poem that offers the imago of another heroine, the sleeping Cynthia as vulnerable to rape. Ovid, of course, is influenced primarily by Prop. 1.3 in the representation of Ariadne as an elegiac sleeping puella (already in Heroides 10) ${ }^{58}$ which should be considered as additional evidence that the same poem functions as his inspiration for introducing a new narrative element into the story, which clearly did not exist explicitly in any previous treatments. All the evidence leads to the Propertian elegy (1.3) influencing the rape setting in the Ariadne episode, which justifies this innovative re-telling of the story. The rape, on the one hand, enhances the elegiac tone because it reminds the readers of other elegiac passages with similar content, namely Prop. 1.3, that begins with a juxtaposition of the elegiac puella to the sleeping Ariadne. On the other hand, it lends a playful (comic) tone to the episode, as it recalls similar scenes from

Propertius with Bacchus and hence both are linked with rape. Booth 1995: 24 discusses the erotic connotations of the vocabulary used at Prop. 1.3.15-16 and highlights the concept of rape. The scholar indicates that at verses 27-30 the poet imagines that the sleeping Cynthia's timores derive from fear of rape from an unwanted lover. Hubbard 2001: 21 mentions that Propertius 'thinks of rape' and then reconsiders.

58 Although any possible similarities between Ovid's treatment of Ariadne and Propertius' treatment of Cynthia in 1.3 could be initially indebted to a common model, i. e. Catullus 64, it is important to take into consideration the fact that Propertius' literary influence on Ovid is evident throughout his poetic career. On the Catullan influence on Prop. 1.3 see Breed 2003. Prop. 1.3 begins with Cynthia being compared to three mythological heroines, the first of which is Ariadne, in order to define two of her traits, the puella has been abandoned and she is sleeping (Prop. 1.3.1-2, 25), which is echoed by Ovid's brief reference to Ariadne at Am. 1.7.15-16. On Ovidian allusion to Propertius 1.3 see Morgan 1977: 70-72, who discusses the intertextual dialogue between Amores 1.10 and the Propertian elegy. 
comedy and establishes a connection to theatre and dramatic performances. Of course, this playful tone is strengthened with the description of the god's entourage. ${ }^{59}$

However, Ariadne is not the only Ovidian heroine that is portrayed as a rape victim within the first book of the Ars Amatoria. The rape of the Sabine women is narrated at lines 89-134, which precede the Ariadne story; hence, Ovid has already composed one rape narrative within the context of this book, which suggests that the outcome of the comparison will be valid. The first major similarity between the two passages is found in their introduction as aetiological stories. ${ }^{60}$ Both episodes offer aetia, explaining simultaneously the incorporation of these female characters within the work. On the one hand, Ovid uses the Sabine women episode to justify the advice aimed at his male readers: the best meeting place is the theatre (Ars am. 1.89) and it has been since the time of Romulus, as it becomes evident by the abduction of the Sabine women and their characterisation as rapta (Ars am.1.102). Additionally, the theatre is a suitable meeting place for both his male readers and women. The praeceptor amoris begins the narration of the story with the explicit reference to theatre in order to offer an aetion for women's presence there: they come to the theatre 'to see' and 'to be seen' (spectatum veniunt, veniunt spectentur ut ipsae, Ars am. 1.99). Thus, according to male perspective, theatre is also beneficial to women, who within the amatory world of the Ars Amatoria, are both spectators and spectacle. The imago of female heroines within the work is constructed carefully, as the poet plays with the boundaries of female portrayal. On the other hand, the praeceptor amoris' reference to Liber, prior to the Ariadne episode, offers an amatory explanation for the incorporation of the heroine's story; the god assists lovers, because

59 Cf. Ov. Ars am. 1.543-44: ebrius, ecce, senex pando Silenus asello / vix sedet, et pressas continent ante iubas ('Io! Drunken old Silenus scarce sits his crookbacked ass, and leaning clings to the mane before him'); 1.546-47: quadrupedem ferula dum malus urget eques, / in caput aurito cecidit delapsus asello ('and while the unskilful horseman urges his beast with a rod, he falls off the long-eared ass and topples head-foremost and the Satyrs cry').

60 On the aetiological and humorous tone of the Sabine women episode see Hollis 1973: 105; Watson 2002: 152. On the 'erotic aetiology' of this episode and its cultural connotations see Labate 2006. For a comparative reading of the rape of the Sabine women in Livy (1.9-13) and Ovid's Ars Amatoria see Beard 1999. 
he is also consumed by the flammae of amor (Ars am. 1.525-26). The passages are subtly interlinked: Liber is associated with dramatic performances and music, as highlighted by the text itself ${ }^{61}$ creating a visual and acoustic nod to the image of spectators and spectacles at the theatre. Not only is the god associated with these images, but by the end of the episode Ariadne herself becomes the epitome of a spectacle, as both her figura and her crown are transformed into a star, thus providing an aetion for the Cressa Corona (Ars am. 1.558). ${ }^{62}$

In addition to the aetiological aspect, which is considered a main function of later Ovidian rape narratives, both stories portray their heroines as rape victims. To begin with, the association of paleness and fear, foreshadowing the rape, appears in both episodes. The image of a puella losing her color because of fear becomes a connecting thread between the Sabine women and Ariadne (constitit in nulla qui fuit ante color 'in none remained her former colour', Ars am. 1.120; et color et Theseus et vox abiere puellae 'voice, colour and Theseus all were gone from the girl', Ars am. 1.551). Additionally, fear is connected not only with absence of colour, but also with the heroines' attempt to flee; with the imagery of flight, triggered by fear, indicated with the verbs fugit/timuere in the case of the Sabines at verses 118-19 and the nouns fugam/metu in the case of Ariadne at verse 552 respectively. What seems to be the common factor in both episodes is that the portrayal of a frightened woman or women seems to

61 Cf. Ov. Ars am. 1.111-14: dumque, rudem praebente modum tibicine Tusco / ludius aequatam ter pede pulsat humum, / in medio plausu (plausus tunc arte carebant) / rex populo praedae signa petita dedit. ('And while to the Tuscan flute-player's rude strains the dancer struck thrice with his foot the levelled floor, in the midst of the applause (the applause then was rough and rude) the king gave to the people the expected sign of rape'.) Ov. Ars am. 1.537-38: 'quid mihi fiet?' ait: sonuerunt cymbala toto / litore, et attonita tympana pulsa manu. ('What will become of me?' she cries: then all the shore cymbals resounded and drums beaten by frenzied hands.')

62 Cf. McKeown 1989: 173 on Ov. Am. 1.7.15-16, who suggests that the characterisation Cressa, attributed to Ariadne, could be an implicit reference to the Cretans' reputation as liars and creates the impression that 'a woman whom one might have expected to be deceitful has been deceived.' Ryan \& Perkins 2011: 78 ad loc. offer a different interpretation and suggest that this particular reference might be indicative of the heroine's 'passivity and vulnerability'. Regarding the Ariadne digression in the Ars, it is evident that the heroine's vulnerability is highlighted through this reference. On the heroine's vulnerability in the Ars see Armstrong 2006: 244. 
enhance their attractiveness in the eyes of the husband(s) to be ${ }^{63}$ which is used to 'justify' their construction or, in Ariadne's case, de-construction as rape victims.

Moreover, the victimisation of both the Sabine women and Ariadne is made explicit with the use of specific language in relation to these female characters. The attribution of the adjective raptae at verse 125 to the Sabine women underlines their image as 'abducted' heroines, taken by force (hence their characterisation as praeda in the same verse). This imago of 'abducted' heroines continues with the use of the verb repugnarat at verse 127 to establish the ever-changing status of the heroines, who 'transform' from spectators, to the object of male gaze,$^{64}$ to raptae puellae, to praeda, to uxores. ${ }^{65}$

63 Richlin 1992: 168.

64 See Hollis 1977: 56 on Ov. Ars am. 1.121-24, who suggests that it is possible that Ovid is influenced by 'some pictorial representation' in his visualisation of the Sabine women.

65 Cf. Ov. Ars am. 1.125: ducuntur raptae, genialis praeda, puellae ('the captured women are led off, spoil for the marriage couch'); Ov. Ars am. 1.127-28: si qua repugnarat nimium comitemque negarat, / sublatam cupido vir tulit ipse sinu ('if any struggled overmuch and resisted her mate, up-borne on his eager breast he carried her off himself'). Hollis 1977: 56 on Ov. Ars am. 1.125 highlights that the phrase genialis praeda indicates that the women are seen as a 'spoil for the marriage bed'. Their association with bed imagery establishes an implicit connection with Ariadne, or at least with her ecphrastic origins. Also, it is notable that in the Metamorphoses, Ovid attributes the characterisation rapta to Ariadne, although in connection to Theseus. In this brief narration of the story with just one word, Ovid implies that the heroine is taken by force the first time (by Theseus) and then with the use of another word (amplexus) hints at her vulnerability and helplessness as Bacchus embraces her. See Ov. Met. 8.174: protinus Aegides rapta Minoide Diam ('straightway the son of Aegeus, taking Minos' daughter'); 8.177-79: amplexus et opem Liber tulit, utque perenni / sidere clara foret, sumptam de fronte coronam/inmisit caelo. [...] ('Bacchus brought love and help. And, that she might shine among the deathless stars, he sent the crown she wore up to the skies'). The use of amplexus reminds us of another rape victim within the world of the Metamorphoses. The comment of Johnson 1996: 11 on the scene between the deceitful Jupiter - transformed into Diana - embracing Callisto is poignant: 'Amplexus (433) is perhaps a deliberately tacky euphemism [...] for she is as unsuspecting and helpless as he is invincible.' 
Therefore, even though the situation is not identical, both episodes indicate explicitly the forthcoming marital status of the women in question, associating it with a 'romanticisation' of amatory violence. ${ }^{66}$ In the Sabine women episode, the praeceptor amoris comments on the fact that if any of the women attempted to fight back, then the husband-to-be would carry her off and offer marriage to her (quod matri pater est, hoc tibi' dixit 'ero.', 'saying: what your father was to your mother that will I be to you', Ars am. 1.130). ${ }^{67}$ In the Ariadne episode, the heroine (unlike some of the Sabine women) does not have the strength to fight and surrenders (neque enim pugnare valebat, Ars am.1.561), though she attempts to escape (Ars am. 1.552). The use of the verb pugno in association with the negative neque creates an interesting parallel with the Sabines' attempt to fight back. Whereas at least some of the Sabines choose fight and not flight, Ariadne chooses flight because her battle is un-even (Ars am.1.562). However, exactly like the Sabine women, she is offered a new marital status (uxor eris, Ars am. 1.556), which is fulfilled by the end of the episode as indicated by the use of nupta at verse 564 . As demonstrated by the text itself, male gaze and male speech are the dominant features of these passages. Women within the boundaries of these two passages have no voice (in the Sabine women digression) or lose their voice (in the Ariadne digression), which is contrasted with the dominance of the male voice of the praeceptor amoris and his male exempla. Bacchus' speech echoes that of the un-named man in the Sabine episode as they are both characterised by an amatory and paternalistic tone: ${ }^{68}$ the women in question are told their fate without any possibility of challenging it, as it is indicated with the repetition of the future tense of the verb sum (ero and eris). Their resistance and attempt to fight is a necessary inconvenience for the male suitors and a central component of their amatory struggle within the Ars, that will be overcome with the instructions of the praeceptor amoris. ${ }^{69}$

66 The term 'romanticisation of force' and its function as a motif for the first book of the Ars Amatoria in particular is suggested by Sharrock 2006.

67 Hollis 1977: 56 ad loc. suggests that this line indicates that Ovid alludes to traditional justifications of rape.

68 For this element in the Sabine rape narrative see Richlin 1992: 167.

69 On the notion of 'feminine resistance that is portrayed as a necessary part of the game' in the Sabine women episode see Labate 2006: 214. 
The striking similarities between the rape of the Sabine women and the Ariadne episode suggest that the poet is creating the setting of another rape in the latter. The main difference, however, between the two episodes is that in the former the rape is mentioned clearly, while in the latter it is simply hinted at. What is more, the abduction of the Sabine women, similarly to the desertion of Ariadne, is a story that finds its place more than once within the Ovidian corpus. The story is re-introduced in the Fasti (3.187-234), where the rape narrative once again leads to marriage. ${ }^{70}$ But as Richlin rightly points outs, 'a text about rape may also be about something else, but it is still a text of rape. ${ }^{71}$

Echoing the episode of the Sabine women in the Ars, the Ariadne digression is narrated and perceived as a light-hearted rape. ${ }^{72}$ Ovid re-imagines the figura of Ariadne: she is no longer the lamenting letter-writer, whose misfortune creates emotions of empathy in her readers; she is a voiceless figura whose new misfortune is given a light-hearted tone, under the dominant male gaze. This tone is suitable for the amatory-didactic purposes of the Ars Amatoria: the male readers of the first two books are to be educated and entertained by the exempla offered by the praeceptor amoris. ${ }^{73}$ By re-interpreting such a famous tale and de-constructing such a notable woman of myth, Ovid affirms his role as the teacher of love and illustrates his ability to re-imagine a heroine, who albeit her Greek literary origins - was a literary model for the portrayal of women in Latin literature.

70 Hejduk 2011: 21 argues that the story of the Sabine women, as the abduction of Persephone, 'which culminate in stable marriages, are in a different category from the one-night lust-driven attacks that usually merit the name of 'rape'.'

71 Richlin 1992: 159.

72 Cf. Murgatroyd 2000: 80 n. 20, who argues that both the Sabine women episode and the Achilles-Deidamia episode are 'light-hearted rapes which poke fun at the Rapists'.

73 Hollis 1977: 125 on Ov. Ars am. 1.562 underlines the amusing tone of the Ovidian comment in the parenthesis: the praeceptor amoris' male reader will probably face difficulties in his amatory adventures, compared to the omnipotent god. 


\section{CONCLUDING REMARKS}

As the discussion has illustrated, at Ars am. 1.527-64 Ovid presents a deconstruction of Ariadne's imago as the deserted lamenting heroine whose status as one of the letter-writers of the Epistulae Heroidum seems forgotten and is purposefully transformed into the voice-less and helpless victim of a rape narrative. This metamorphosis has its origins in the poet's playful dialogue with his fellow-elegist Propertius (1.3). Ovid alludes explicitly to both Catullus' original speaking heroine (64) and to his own representation of Ariadne not simply as a speaking heroine but as a letter-writer (Her. 10), establishing thus a connecting thread between these mirror imagines of Ariadne. However, the poet also alludes implicitly to Propertius' description of the ideal elegiac puella in 1.3, who - not coincidentally - is connected with the imago of Ariadne. Until this point, Ariadne is synonymous with amatory abandonment and lamentation. Ovid breaks the mould and adds a new characteristic: Ariadne is not simply a deserted heroine lamenting the loss of amor; she is a deserted heroine facing the consequences of what is labelled amor from a male perspective. Thus, the Ovidian reader embarks on a journey of re-interpretation and re-imagination, discovering along the way the origins and the transformation of one of the most famous Ovidian heroines. ${ }^{74}$

\section{BIBLIOGRAPHY}

Adams, J.N. 1982. The Latin Sexual Vocabulary. London.

Anderson, W.S. 1996. Ovid's Metamorphoses. Books 1-5. Edited with Introduction and Commentary. Norman, Oklahoma.

Armstrong, R. 2006. Cretan Women: Pasiphae, Ariadne, and Phaedra in Latin Poetry. Oxford.

Barchiesi, A. 2001. Speaking Volumes: Narrative and intertext in Ovid and other Latin poets. London.

Battistella, C. 2010. P. Ovidii Nasonis Heroidum Epistula 10: Ariadne Theseo. Introduzione, Testo e Commento. Berlin \& New York.

74 I am grateful to Prof. Spyridon Tzounakas and Dr. Stella Alekou, as well as the reviewer for their valuable suggestions and thoughtful comments. 
Beard, M. 1999 'The Erotics of Rape: Livy, Ovid, and the Sabine Women' in P. Setälä \& L. Savunen (eds.) Female Networks and the Public Sphere in Roman Society. Rome, 1-10.

Blodgett, E.D. 1973. 'The Well Wrought Void: Reflections on the Ars Amatoria' CJ 68.4, 322-33.

Bömer, F. 1958. P. Ovidius Naso. Die Fasten. Vol. II. Kommentar. Heidelberg. Booth, J. 1995. Latin Love Elegy: A Companion to the Translations of Guy Lee. Bristol.

Breed, B.W. 2003. 'Portrait of a Lady: Propertius 1.3 and Ecphrasis' CJ 99.1, 35-56.

Conte, G.B. (ed.) 2009. P. Vergilius Maro. Aeneis. Berlin.

Deroux, C. 1986. 'Some Remarks on the Handling of Ekphrasis in Catullus 64' in C. Deroux (ed.) Studies in Latin Literature and Roman History. Vol. 4. Brussels, 247-58.

Duban, J. 1980. 'Verbal links and Imagistic Undercurrent in Catullus 64' Latomus 39, 777-802.

Dufallo, B. 2013. The Captor's Image: Greek Culture in Roman Ecphrasis. Oxford.

Eisenhut, W. (ed.) 1983. Catulli Veronensis Liber. Leipzig.

Fredrick, D. 1998. 'Reading Broken Skin: Violence in Roman elegy' in J.P. Hallet \& M.B. Skinner (eds.) Roman Sexualities. Princeton, 172-93.

Forsyth, P.Y. 1980. 'Catullus 64: Dionysus reconsidered' in C. Deroux (ed.) Studies in Latin Literature and Roman History. Vol. 2. Brussels, 98-105.

Fulkerson, L. 2005. The Ovidian Heroine as Author: Reading, Writing and Community in the Heroides. Cambridge.

Fulkerson, L. 2016. Ovid: A Poet on the Margins. London \& New York.

Gibson, R.K. 2007. Excess and Restraint: Propertius, Horace and Ovid's Ars Amatoria. London.

Glare, P.G.W. (ed.) 1968. Oxford Latin Dictionary. Oxford. [OLD]

Godwin, J. 1995. Catullus: Poems 61-68. Edited with Introduction, Translation and Commentary. Warminster.

Goold, G.P. \& W.H.S. Jones (eds.) 1918. Pausanias. Description of Greece. Vol. I (Loeb Classical Library). Cambridge, MA \& London.

Goold, G.P. \& G. Showerman (eds.) 1986². Ovid. Heroides and Amores. Vol. 1 (Loeb Classical Library). Cambridge, MA \& London. 
Goold, G.P. \& J.H. Mozley (eds.) 1979². Ovid. The Art of Love and other poems. Vol. 2 (Loeb Classical Library). Cambridge, MA \& London.

Goold, G.P. \& G. Frazer (eds.) 1989². Ovid. Fasti. Vol. 5 (Loeb Classical Library). Cambridge, MA \& London.

Goold, G.P. (ed.) 1990. Propertius. Elegies (Loeb Classical Library). Cambridge, MA \& London.

Goold, G.P. \& H.R. Fairclough (eds.) 1999. Virgil. Eclogues. Georgics. Aeneid IVI (Loeb Classical Library). Cambridge, MA \& London.

Greene, E. 1998. The Erotics of Domination: Male Desire and the Mistress in Latin Love Poetry. Baltimore.

Harries, B. 1989. 'Causation and the Authority of the Poet in Ovid's Fasti' CQ 39.1, 164-85.

Harrison, S.J. 1994. 'Drink, Suspicion and Comedy in Propertius 1.3' PCPhS 40, 18-26.

Harrison, S.J. 2002. 'Ovid and genre: evolutions of an elegist' in P. Hardie (ed.) The Cambridge Companion to Ovid. Cambridge, 79-94.

Hejduk, J.D. 2011. 'Epic Rapes in the Fasti' CPh 106.1, 20-31.

Heyworth, S.J. (ed.) 2007a. Sexti Properti Elegi. Oxford.

Heyworth, S.J. 2007b. Cynthia: A Companion to the Text of Propertius. Oxford. Hill, D.E. 1992. Ovid. Metamorphoses V-VIII. Edited with Translation and Notes. Warminster.

Hollis, A.S. 1977. Ovid: Ars Amatoria. Book I. Edited with Introduction and Commentary. Oxford.

Holzberg, N. 2006. 'Staging the Reader Response: Ovid and his 'Contemporary Audience' in Ars and Remedia' in R. Gibson, S. Green \& A. Sharrock (eds.) The Art of Love: Bimillenial Essays on Ovid's Ars Amatoria and Remedia Amoris. Oxford, 40-53.

Hubbard, M. 2001. Propertius. London.

James, S.L. 2003a. Learned Girls and Male Persuasion: Gender and Reading in Roman Love Elegy. Berkeley.

James, S.L. 2003b. 'Her Turn to Cry: The Politics of Weeping in Roman Love Elegy’ TAPhA 133.1, 99-122.

Johnson, W.R. 1996. 'The Rapes of Callisto' CJ 92.1, 9-24.

Jolivet, J.C. 2001. Allusion et Fiction Épistolaire dans les Héroïdes: Recherches sur l'intertextualité Ovidienne. Rome. 
Kenney, E.J. (ed.) 1994. P. Ovidi Nasonis Amores, Medicamina faciei femineae, Ars amatoria, Remedia amoris. Oxford.

Kidd, D. (ed.) 1997. Aratus: Phaenomena. With Introduction, Translation and Commentary. Cambridge.

Kinsey, T.E. 1965. 'Irony and Structure in Catullus 64' Latomus 24, 911-31. Labate, M. 2006. 'Erotic Aetiology: Romulus, Augustus, and the Rape of the Sabine Women' in R. Gibson, S. Green \& A. Sharrock (eds.) The Art of Love: Bimillenial Essays on Ovid's Ars Amatoria and Remedia Amoris. Oxford, 193-215.

Liddell, H.G. \& R. Scott (eds.) 1940․ A Greek-English Lexicon. Revised by H.S. Jones et al. Oxford. [LSJ]

Lindheim, S.H. 2003. Mail and Female: Epistolary Narrative and Desire in Ovid's Heroides. Madison, WI.

Lyne, R.O.A.M. 2007. Collected Papers on Latin Poetry. Oxford.

Martelli, F.K.A. 2013. Ovid's Revisions: The Editor as Author. Cambridge.

McKeown, J.C. 1989. Ovid: Amores. Text, Prolegomena and Commentary in four volumes. A Commentary on Book One. Vol. 2. Leeds.

Miller, P.A. 2004. 'The Parodic Sublime: Ovid's Reception of Virgil in Heroides 7' MD 52, 57-72.

Morgan, K. 1977. Ovid's Art of Imitation: Propertius in the Amores (Mnemosyne Suppl. 46-48). Leiden.

Morrison, J.V. 1992. 'Literary Reference and Generic Transgression in Ovid, Amores 1.7: Lover, Poet, and Furor' Latomus 51, 571-89.

Murgatroyd, P. 1994. 'Deception and Double Allusion in Ovid A.A. 1.527564’ Mnemosyne 47.1, 87-93.

Murgatroyd, P. 2000. 'Plotting in Ovidian Rape Narratives' Eranos 98, 7592.

Murgatroyd, P. 2005. Mythical and Legendary Narrative in Ovid's Fasti (Mnemosyne Suppl. 263). Leiden \& Boston.

Putnam, M.C.J. 1972. 'The Art of Catullus 64' in K. Quinn (ed.) Approaches to Catullus. Cambridge, 225-65.

Race, W.H. (ed.) 2008. Apollonius Rhodius. Argonautica (Loeb Classical Library). Cambridge, MA \& London.

Richlin, A. 1992. 'Reading Ovid's Rapes' in A. Richlin (ed.) Pornography and Representation in Greece and Rome. New York \& Oxford, 158-79. 
Rimell, V. 2006. Ovid's Lovers: Desire, Difference and the Poetic Imagination. Cambridge.

Robinson, M. 2011. A Commentary on Ovid's Fasti, Book 2. Oxford.

Ryan, M.B. \& C.A. Perkins 2011. Ovid's Amores, Book One. A Commentary. Norman.

Sharrock, A. 2002. 'Ovid and the discourses of love: the amatory works' in P. Hardie (ed.) The Cambridge Companion to Ovid. Cambridge, 150-62.

Sharrock, A. 2006. 'Love in Parentheses: Digression and Narrative Hierarchy in Ovid's Erotodidactic Poems' in R. Gibson, S. Green \& A. Sharrock (eds.) The Art of Love: Bimillenial Essays on Ovid's Ars Amatoria and Remedia Amoris. Oxford, 23-39.

Spentzou, E. 2003. Readers and Writers in Ovid's Heroides: Transgressions of Genre and Gender. Oxford.

Tatham, D. 2000. 'Just as Ariadne Lay...': Images of Sleep in Propertius 1.3' Scholia 9, 43-53.

Von Glinsky, L. 2012. Simile and Identity in Ovid's Metamorphoses. Cambridge 2012.

Warden, J. 1998. 'Catullus 64: Structure and Meaning' CJ 93.4, 397-415.

Warmington, E.H. \& F.J. Miller (ed.) $1921^{2}$. Ovid. Metamorphoses. 2 Vols. (Loeb Classical Library). Cambridge, MA \& London.

Watson, P. 2002. 'Praecepta amoris: Ovid's didactic elegy' in B. Weiden Boyd (ed.) Brill's Companion to Ovid. Leiden \& Boston, 141-65.

Weiden Boyd, B. 1997. Ovid's Literary Loves. Influence and Innovation in the Amores. Ann Arbor.

Wiseman, T.P. 1977. 'Catullus' Iacchus and Ariadne' LCM 2, 177-80.

Despina Keramida

University of Cyprus

keramida.despina@ucy.ac.cy 